\title{
FIRE RESISTANCE TESTS OF ALUMINIUM GLAZED PARTITIONS Results comparison
}

\author{
Bartłomiej Sędłak, Jacek Kinowski, Daniel Izydorczyk, Paweł Sulik \\ Building Research Institute, Fire Research Department, Ksawerów 21 St., 02-656 Warsaw, Poland
}

\begin{abstract}
This paper discusses the main problems related to the fire resistance of aluminium glazed partitions, including the tests methodology and way of classification of this type of elements. Moreover, the paper presents the comparison of fire resistance test results of glazed partition test specimens, depending on the number of insulation inserts placed inside the aluminium structure profiles. To made the comparison the specimens with the same transom - mullion structure were tested in two configurations and with two filling solutions - with profiles filled only in the middle part and with fully filled profiles.
\end{abstract}

Keywords: glazed partition, aluminium profiles, insulation inserts, integrity, fire resistance

\section{INTRODUCTION}

The partition wall is a type of the inner wall in the building. It does not form the structure, and thus is designed in such a way that it is not exposed to any other loads beyond its own weight. According to the regulations of many European Union countries (in case of buildings for a specific purpose, e.g., hospitals, hotels) partition walls as a non-load bearing elements of building should be designed and constructed in such a way that in case of fire it will limit the spread of fire and smoke in the building, allow the evacuation of users and ensure the safety of rescue team. Therefore, in this type of buildings partition walls shall fulfil the requirements of fire resistance. There are many types of fire resistance partitions commonly used in Europe (e.g., gypsum-plasterboards walls, sandwich panel walls, steel glazed partitions, timber glazed partitions or aluminium glazed partitions). Because of the subject only the last one from listed above will be discussed in this paper. Fire resistance class of aluminium glazed partitions cannot be calculated or assessed on the basis of its project. The only way to determine the real fire resistance class is to perform the fire resistance test.

\section{TECHNICAL SOLUTIONS}

Aluminium glazed partitions with a specific fire resistance class have a frame (mullion - transom) structure in which the areas between the aluminium profiles are filled with special fire resistant glass panes. The most commonly used in practice are three-chamber profiles made of two aluminium parts connected by means of thermal separators (e.g., made of polyamide reinforced with glass fiber). In order to ensure the insulation and reduce the adverse impact of thermal effects, chambers of the profiles are filled with the insulation inserts (e.g., made of plasterboard, cement silicate or calcium silicate). The use of three-chamber profiles is a reasonable option from an economic point of view - at the same profiles by changing the type or the volume of fulfillment or size of thermal insulator (change of cross-section of the middle chamber) can be achieved different classes of fire resistance. (Sędtak, 2013).

The glass panes are fixed to the profiles by means of properly arranged steel angles, covered with "clip on" or screwed on glazing beads. Important elements in the profile structure are intumescent gaskets placed on the perimeter of the glass panes. Intumescent gaskets expands under the influence of high temperatures and close the spaces through which the fire could get to the other side of the partition.(Sędtak et al., 2014)

Example profile cross-section is presented in fig. 1. 


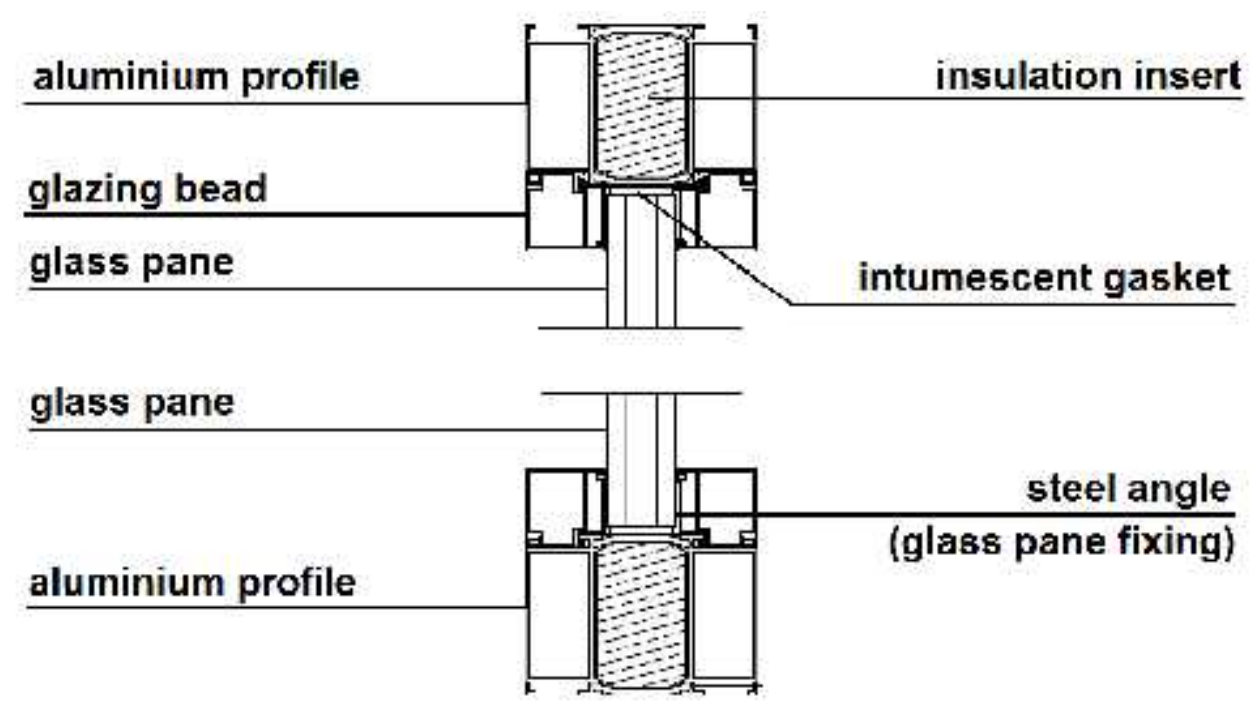

Fig. 1 Example profile cross-section (Sędtak, 2015)

Increasingly common in the market solution is "fully glazed partition" (Sedtak, 2014), in which the aluminium profiles are used only along the perimeter of the partition, mullions are replaced by a special fireproof silicone or intumescent gaskets, and the transoms in most cases do not occur. (Secltak, 2015)

\section{FIRE RESISTANCE TESTS AND CLASSIFICATION}

As it was written in the first chapter the only way to determine the real fire resistance class of the specific aluminium glazed partition is to perform the fire resistance test of its fully representative specimen (including any surface finishes and fittings which are essential and may influence its behavior in the test). If the partition wall has a symmetrical cross-section, then it is sufficient to test it only from one side. In other case, it is necessary to check the wall from both sides in order to get fully assessment.

Heating of the test specimen is held by the standard temperature-time curve, presented by the solid line in fig. 2, which is taken as an appropriate to reflect the fully developed, following the flashover fire inside the building.

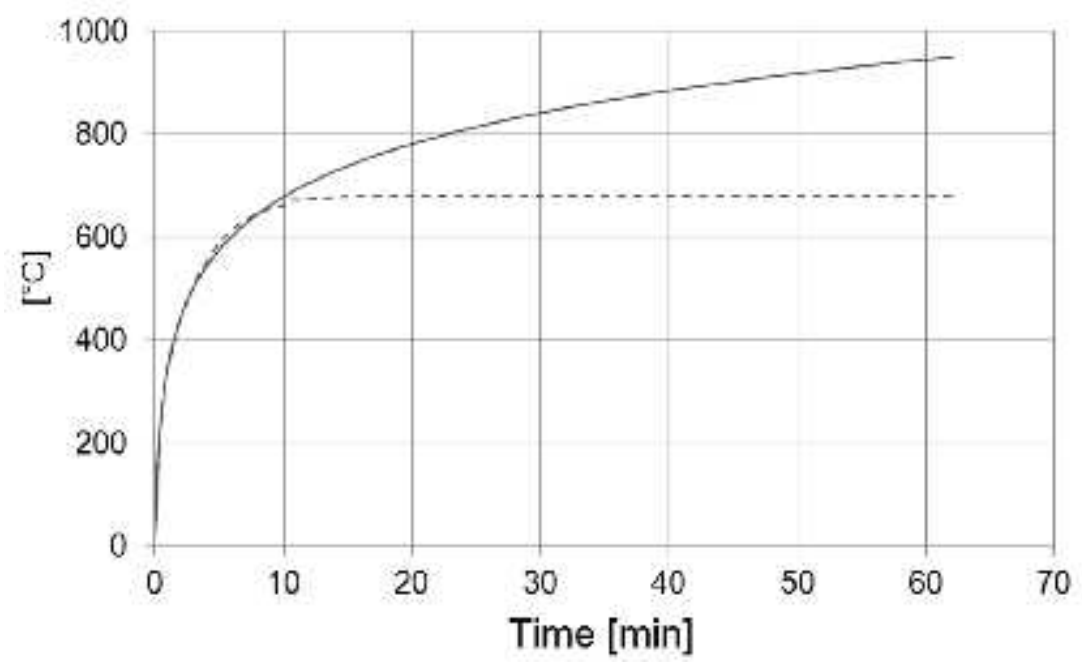

Fig. 2 Temperature-time curves, solid line - standard curve, dashed line - external fire curve (Sędtak, 2014)

During the fire resistance test of aluminium glazed partitions the effectiveness of the following performance criteria can be verified: integrity (E), insulation (I) and radiation (W). 
Integrity is the ability of glazed partition test specimen, when exposed to fire on one side, to prevent the passage through it of hot gases and flames and to prevent the occurrence of flames on the unexposed side. During the test integrity is verified:

- visually (it fails when on the unexposed surface of tested specimen flaming longer than $10 \mathrm{~s}$ occurs),

- by means of cotton pad, which is used against the unexposed surface of tested specimen, for max. of $30 \mathrm{~s}$, or until ignition (defined as glowing or flaming),

- by means of gap gauges (integrity fails if the $6 \mathrm{~mm}$ gap gauge can be passed through the test specimen and can be moved a distance of $150 \mathrm{~mm}$ along the gap, or if the $25 \mathrm{~mm}$ gap gauge can be passed through the test specimen such that it projects into the furnace).

Insulation is the ability of glazed partition test specimen when exposed to fire on one side, to restrict the temperature rise of the unexposed face to below specified levels. The temperature rise on the unexposed surface of tested specimen is verified with thermocouples attached with use of heat resistant adhesive. Thermocouples are attached in the specific places given in the appropriate standard. (Roszkowski et al., 2011)

In case of aluminium glazed partitions, in order to maintain its insulation - maximum temperature rise on the profiles cannot be greater than $180 \mathrm{~K}$ and average temperature rise on each glazing cannot be greater than $140 \mathrm{~K}$.

Radiation is the ability of a glazed partition test specimen, when exposed to fire on one side, to prevent the passage of the fire, due to the transfer of significant heat through the element or through its unexposed surface to the adjacent materials. Radiation in the test is measured with the radiometer placed in the distance of $1 \mathrm{~m}$ from the geometric center of the unexposed surface of tested specimen. Radiation is evaluated on the basis of the time at which the maximum radiation measured does not exceed $15 \mathrm{~kW} / \mathrm{m}^{2}$.

Moreover, during the test deflection of the test specimen shall be measured although there are no performance criteria associated with it. The deflection of the test specimen may be important in determining the direct and/ or extended field of application field of application of the test result.(Sulik, et al., 2015)

Classification of aluminium glazed partition fire resistance is prepared basing on the test results presented in test report. According to the European Union provisions the fire resistance test shall be performed in accordance with EN 1364-1:1999 and the classification shall be compiled in accordance with the requirements given in EN 13501-2:2009.

Table 1 Possible fire resistance classes (Sędtak et al., 2012)

\begin{tabular}{|c|c|c|c|c|c|c|c|c|c|}
\hline $\mathrm{E}$ & & 20 & 30 & & 60 & 90 & 120 & & \\
\hline $\mathrm{EI}$ & 15 & 20 & 30 & 45 & 60 & 90 & 120 & 180 & 240 \\
\hline $\mathrm{EW}$ & & 20 & 30 & & 60 & 90 & 120 & & \\
\hline
\end{tabular}

(E- integrity, $\mathbf{I}$ - insulation, $\mathbf{W}$ - radiation, $\mathbf{M}$ - resistance to mechanical impact $)$

\section{TEST RESULTS COMPARISON}

Four test specimens of glazed aluminium partitions (two dimensions of $415 \mathrm{x} 415 \mathrm{~cm}$, width $\mathrm{x}$ height and two dimensions of $405 \times 350 \mathrm{~cm}$, width $\times$ height), were tested in Fire Testing Laboratory of Building Research Institute in Pionki. Configuration of tested specimen is presented in fig. 3. The specimens were made of the same 3-chamber aluminium profiles filled with the same type of insulation inserts. The profiles cross section of $46 \times 80 \mathrm{~mm}$ (width $\mathrm{x}$ depth) were made of two aluminium elements connected by means of thermal separator $(34 \mathrm{~mm})$ made of polyamide reinforced with glass fiber. For each test specimen configuration two different solutions of profile insulation were used - profiles were filled only in the middle chamber or in all three chambers. Details of the test specimens are presented in table 2. Test results comparison was made for the temperature rises recorded on the middle mullion (Mullion No. 1) and on the mullion placed on the fixed edge (Mullion No. 2). 

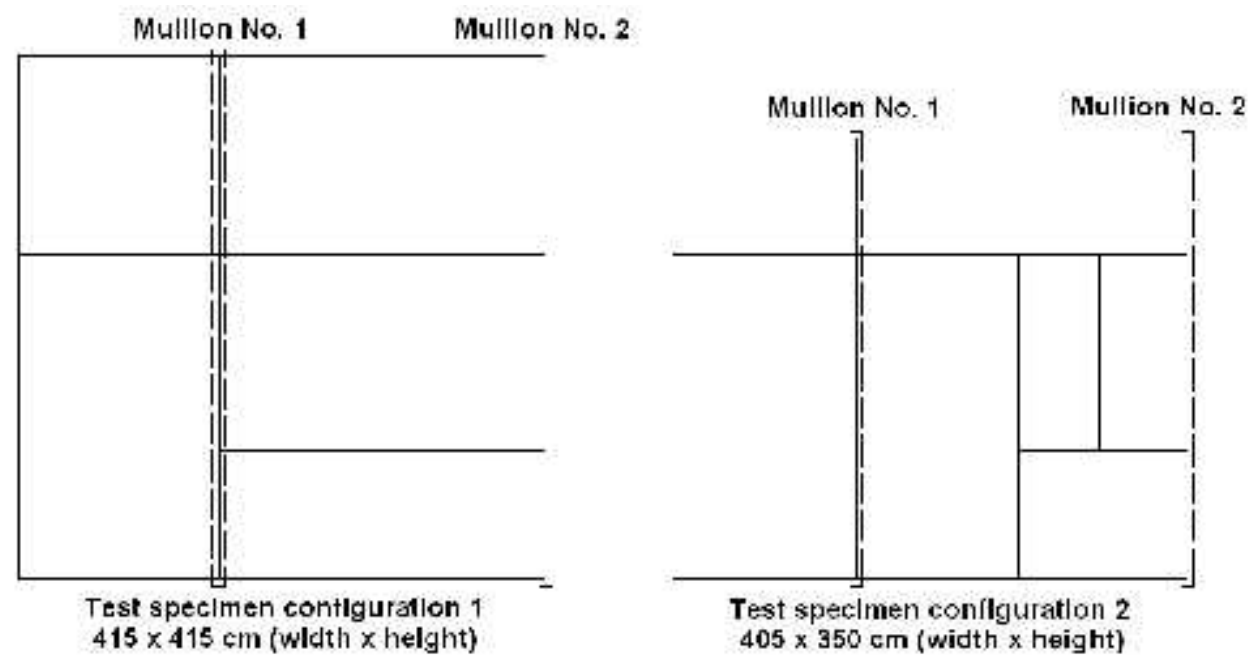

Fig. 3 Test specimens configuration

Table 2 Details of tested specimens

\begin{tabular}{|c|c|c|c|}
\hline Test specimen No. & $\begin{array}{c}\text { Configuration from fig. 3 } \\
\text { / symbol in fig. 4 - 6 }\end{array}$ & $\begin{array}{c}\text { Profile insulation solution / } \\
\text { symbol in fig. 4 - 6 }\end{array}$ & Glazing thickness \\
\hline 1 & $1 / \mathrm{H} 1$ & middle chamber / I1 & $17 \mathrm{~mm}$ \\
\hline 2 & $1 / \mathrm{H} 1$ & full / I & $27 \mathrm{~mm}$ \\
\hline 3 & $2 / \mathrm{H} 2$ & middle chamber / I1 & $17 \mathrm{~mm}$ \\
\hline 4 & $2 / \mathrm{H} 2$ & gull / I & $27 \mathrm{~mm}$ \\
\hline
\end{tabular}

Figure 4 presents the comparison of average temperature rises on mullion No. 1. Figure 5 presents the comparison of average temperature rises on mullion No. 2. Differences between the average temperature rises on the unexposed surface of mullions are presented in fig. 6 .

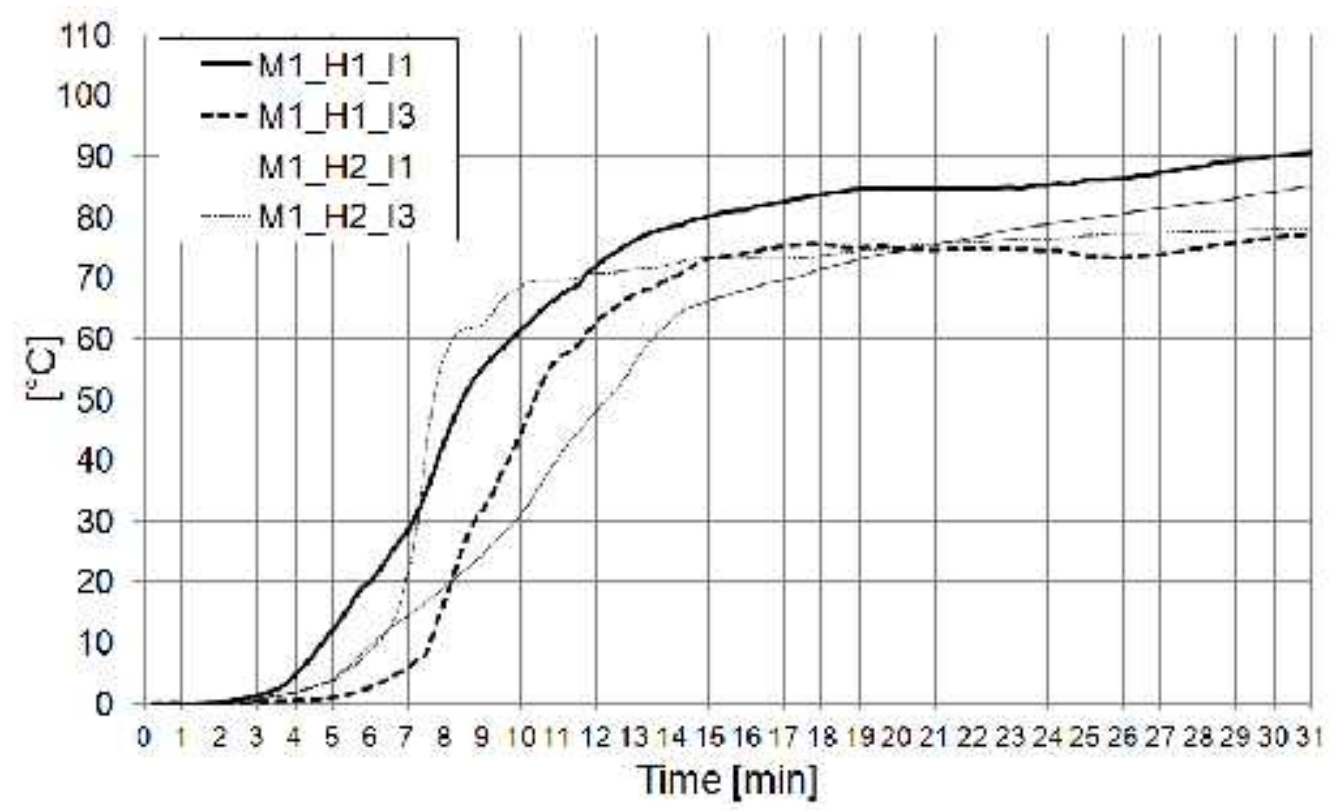

Fig. 4 Comparison of average temperature rises on the mullion No.1 (M1_H1_I1 - Mullion No. 1, configuration No. 1, middle chamber filled, M1_H1_I3 - Mullion No. 1, configuration No. 1, all chambers filled, M1_H2_I1 - Mullion No. 1, configuration No. 2, middle chamber filled, M1_H2_I3 - Mullion No. 1, configuration No. 2, all chambers filled) 


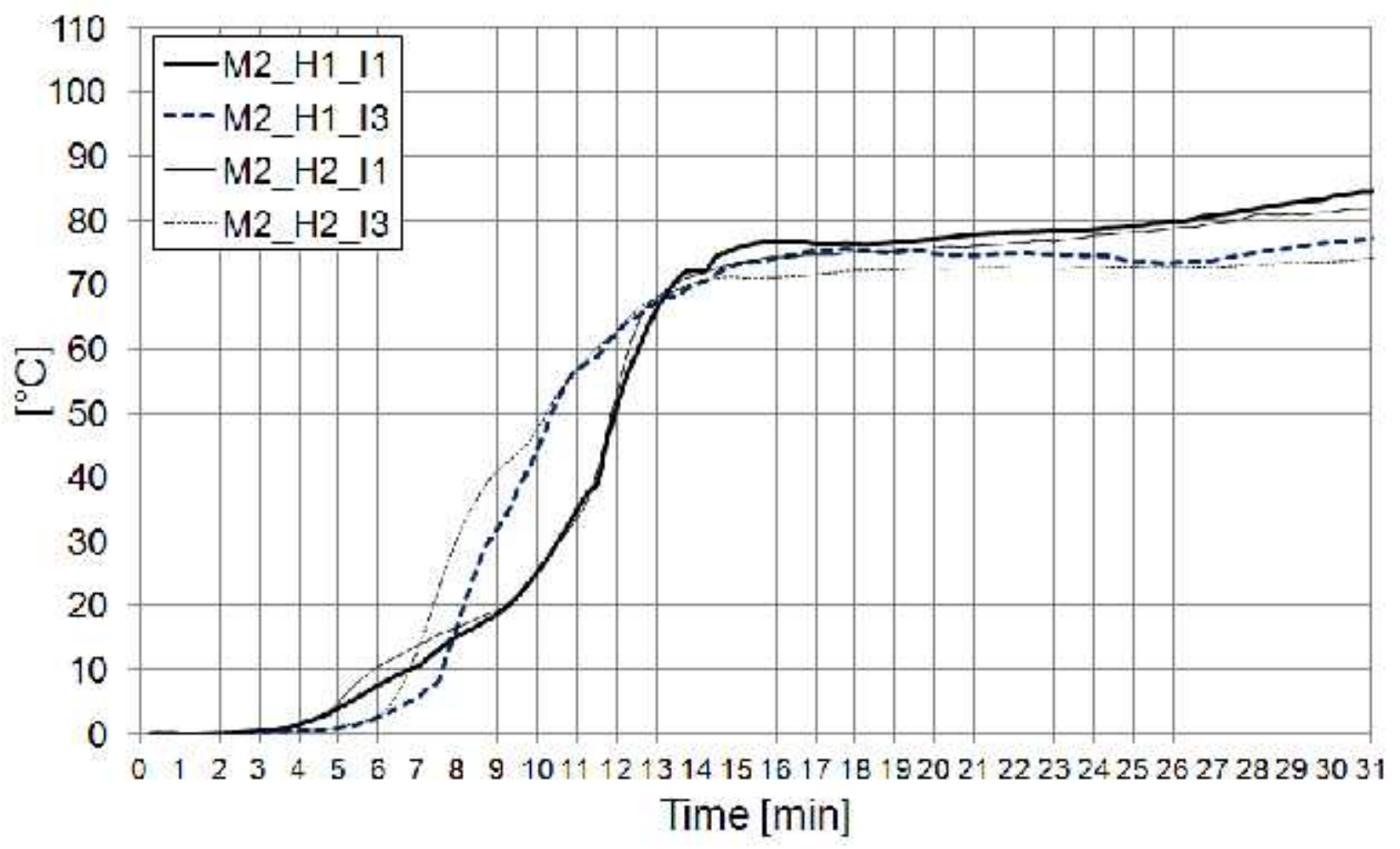

Fig. 5 Comparison of average temperature rises on the mullion No.2 (M2_H1_I1 - Mullion No. 2, configuration No. 1, middle chamber filled, M2_H1_I3 - Mullion No. 2, configuration No. 1, all chambers filled, M2_H2_I1 - Mullion No. 2, configuration No. 2, middle chamber filled, M2_H2_I3 - Mullion No. 2, configuration No. 2, all chambers filled)

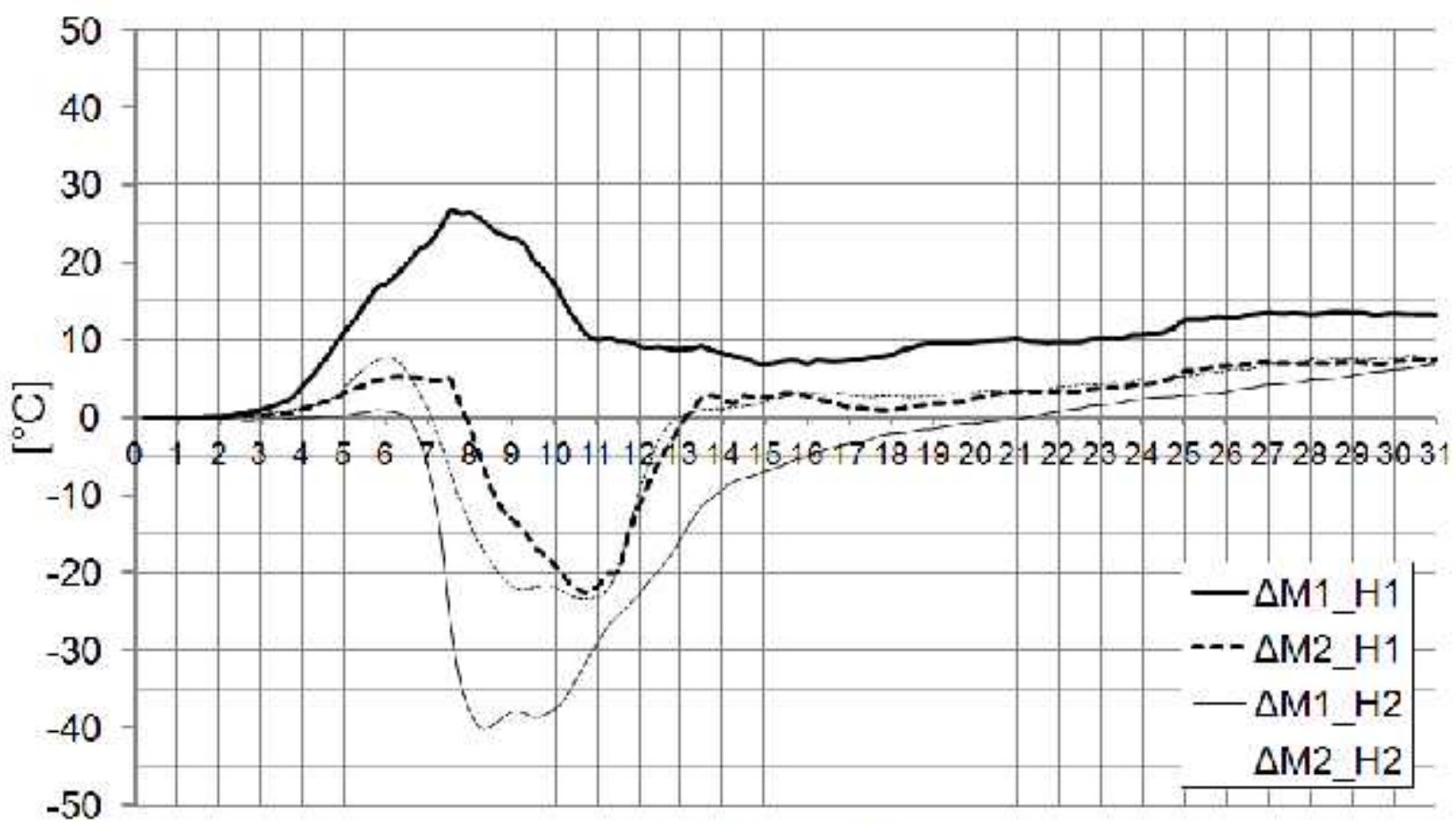

\section{Time [min]}

Fig. 6 Differences between the average temperature rises on the unexposed surface of mullions (M1_H1 Mullion No. 1, configuration No. 1, M2_H1 - Mullion No. 2, configuration No. 1, M1_H2 - Mullion No. 1, configuration No. 2, M2_H2_I3 - Mullion No. 2, configuration No. 2) 


\section{CONCLUSIONS}

Fire resistance of aluminium glazed partitions depends on many factors of the system solution such as: type of glazing, glazing fixing, profile material and shape, type and volume of used insulation inserts. Even a slight change in the structure of the glazed partition can significantly reduce its fire resistance and therefore determining the real fire resistance class of partition wall is only possible on the basis of fire resistance test results.

The graphs presented in Fig. $4-6$ shows the influence of the insulation inserts volume on the temperature rises on the surface of the glazed partition mullion profiles in the first 31 minute of the test. The interesting fact is that between about 8 and 12 minute of the test for mullions in the configuration 2 and for edge mullion of configuration 1 the temperature was greater on the profiles which were theoretically better insulated. Also in this time period the difference between the temperatures recorded on the middle mullion of configuration No. 1 significantly decreased. This phenomenon may be related with the properties of insulation inserts, behavior of fire resistant glass or intumescent gaskets, however its full explanation requires future tests.

\section{REFERENCES}

Roszkowski P., Sędłak B., 2011. Metodyka badań odporności ogniowej przeszklonych ścian działowych. Świat Szkta, 16(9), p. 59-64.

Sędłak B., 2013. Systemy przegród aluminiowo szklanych o określonej klasie odporności ogniowej. Świat Szkta, 18(10), p. 30-33,41.

Sędłak B., 2014. Badania odporności ogniowej przeszklonych ścian działowych. Świat Szkła, 19(2), p. 30-33.

Sędłak B., 2014. Bezszprosowe szklane ściany działowe o określonej klasie odporności ogniowej. Świat Szkła, 19(11), p. 24,26,28,30.

Sędłak B., 2014. Odporność ogniowa ścian osłonowych z du ymi przeszkleniami - Część 1. Świat Szkła, 19(3), p. 16-19,25.

Sędłak B., 2015. Bezpieczeństwo po arowe przeszklonych ścian działowych. Świat Szkła, 20(5), p. 34-40.

Sędłak B., Izydorczyk D., Sulik P., 2014. Fire Resistance of timber glazed partitions. Annals of Warsaw University of Life Sciences - SGGW Forestery and Wood Technology, 85, p. 221-225.

Sędłak B., Roszkowski P., 2012. Klasyfikacja w zakresie odporności ogniowej przeszklonych ścian działowych. Świat Szkta, 17(7-8), p. 54-59.

Sulik P., Sędłak B., 2015. Odporność ogniowa drewnianych przeszklonych ścian działowych. Świat Szkła, 20(3), p. 43-48, 56 